\title{
Biomonitoring application using macrozoobenthic assemblages at coastal area of Menjangan Besar Island, Kepulauan Karimunjawa, Indonesia
}

\author{
Rafita Farantika ${ }^{\mathrm{a}}$, Sapto Purnomo Putro a, ${ }^{\mathrm{b}}$, Agus Indarjo ${ }^{\mathrm{c}}$ \\ a Department of Biology, Faculty of Science and Mathematics, Diponegoro University, Jl. Prof. H. Soedarto, SH, Tembalang, Semarang, 50275, \\ Indonesia \\ b Center of Marine Ecology and Biomonitoring for Sustainable Aquaculture (Ce-MEBSA), 2and floor, Central Laboratory for Research and Services, \\ Diponegoro University, J. Prof. H. Soedarto, SH, Tembalang, Semarang, 50275, Indonesia \\ c Department of Marine Science, Faculty of Fishery and Marine Science, Diponegoro University, Jl. Prof. H. Soedarto, SH, Tembalang, Semarang, \\ 50275, Indonesia \\ * Corresponding author: saptoputro@live.undip.ac.id
}

\section{Article history}

Submitted 8 June 2019

Revised 29 Augst 2019

Accepted 3 October 2019

Published Online 15 June 2020

\begin{abstract}
The macrozoobenthic structure inhabiting marine ecosystem may be used as a bioindicator of changes in aquatic environmental disturbance. This study is aimed to assess environmental disturbance by application of biomonitoring using macrozoobenthic assemblages at coastal area of Menjangan Besar Island, Kepulauan Karimunjawa, Indonesia. The macrozoobenthic assemblages were assessed at two sampling locations, i.e. floating net cage of monoculture and reference areas. Each sampling location consisted of three stations with three replicates for each station. The samples were taken in two sampling times, i.e. August and November 2018. Data of abiotic parameters included the composition of organic matter content, sediment substrates, DO, pH, salinity, temperature, and water current. Sediments were sampled using Ekman grab from $15 \mathrm{~m}$ deep. The relationship between biotics (macrozoobenthos) and abiotics (physical-chemical factors) was assessed using a non-parametric multivariate procedure (BIO-ENV; Primer 6.1.5). Macrobenthic assemblages consisted of 89 species with the total abundance of 50,071 individuals $/ \mathrm{m}^{2}$, consisting of 52 families and 4 classes of macrozoobenthos. The values of indices were ranging from 2,54-3,40 for diversity index (H'), 0,99 for Pielou's evenness index (e'), and 0,09-0,17 for dominance index (C). The most common classes were a member of Gastropods and bivalves. Diversity and evennes indices exhibited differed by location (monoculture vs reference) and time sampling. Fluctuation of macrobenthic structure was considered as a results of environmental changes spatially and temporally, especially sediment composition and food availability as the form of organic matter. Nitrogen and silt were the most chemical and physical factors influencing the structure of macrozoobenthos ( $r=0,632$; BIO-ENV).
\end{abstract}

Keywords: biomonitoring, macrozoobenthic, Menjangan Besar Island, and Kepulauan Karimunjawa

\section{INTRODUCTION}

Menjangan Besar Island is one of the islands located in Kepulauan Karimunjawa, Jepara Regency, Central Java, Indonesia. The area covers 61 ha, with coastal lines reach 5,026 m. Menjangan Besar Island is included as the Karimunjawa National Park area for fish farming and tourism utilization zones (DPPK, 2012). It has beautiful natural scenery, easy accessibility, and economic development activities in the aquaculture sector (Husain et al., 2016). As ecotourim zone, mapping was considered useful for coastal management (Indarjo, 2014). The island is currently used as one of the aquaculture activities, mostly traditional fish farming. Such activity may potentially disturb surrounding water ecosystem. Syuja et al., (2018) reported that changes in the quality of water caused by farming activity set up at Tembelas Island, Kepulauan Riau has affected organisms inhabiting sediment under the farm, especially on changes in structure of macrozoobenthic.
Macrobenthic animals are organisms that spend a part or all of their lifespans in the bottom of water sediments (sessile, crawling, digging holes, or building tubes), have an important role in decomposition and mineralization processes of organic material in the water, as well as occupying several trophic levels in the food chains (Putro et al., 2018).

Their structure varies spatially and temporally, and are sensitive to environmental disturbance (Dauvin et al., 2004), thus considered as an important part of biomonitoring procedures as a formal protocol in assessing the status of water (Putro et al., 2015; Hernandez-Arana et $a l ., 2003)$. The use of indicator organisms to assess water quality is considerably useful for routine biomonitoring to assess the status of the water ecosystem. Thus, the taxa of indicators can be used as a complementary part or strengthen the assessment of water quality based on physical and chemical parameters (Husain et al., 2016). 
Consequently, further research is urgently needed to determine the quality of aquaculture areas using macrozoobenthic assemblages and to assess the level of environmental disturbance caused by fish faring activities.

\section{RESEARCH METHODS}

The sampling sites were located at Menjangan Besar Island, Kepulauan Karimunjawa, Central Java, Indonesia at the coordinates between $110^{\circ} 25^{\prime} 40^{\prime}-110^{\circ} 25^{\prime} 50^{\prime} \mathrm{E}$ and $5^{\circ} 53^{\prime} 10^{\prime}-5^{\circ} 53^{\prime} 0^{\prime} \mathrm{S}$. Two sampling locations were assessed with three stations and three replicates for each location, i.e. floating net cage of monoculture and reference area.

The base sediments were taken from the two locations using Eckman Grab. Each sediment sample was put into a $2 \mathrm{~L}$ plastic jar, containing $10 \%$ of formalin and $70 \%$ ethanol solutions. The measurement of the physics-chemical water parameters was done three times for each location. The parameters measured in this study were $\mathrm{pH}$, temperature $\left({ }^{\circ} \mathrm{C}\right)$, dissolved oxygen (DO), water current, and salinity. Sediment samples were further analysed for each sampling station for sediment composition (coarse sand, fine sand, silt, and clay) and organic contents (total carbon and nitrogen organics).

Data of biotic and abiotic parameters were presented in tables, pie diagrams, and histogram with a standard deviation. The samples were taken in two sampling times, i.e. August and November 2018. Macrozoobenthic identification was done at finest taxonomic resolution (species or genus) using identification books as references, followed by enumeration for total abundance, number of species, and tabulation.

The relationship between biotics (macrozoobenthic) and abiotics (physical-chemical factors) was assessed using a non-parametric multivariate procedure (BIO-ENV). The strength of correlation was expressed by the $r$ value (Clarke and Gorley, 2006). The diversity of the macrozoobenthic assemblages was analyzed using Shanon-Wiener diversity index ( $\left.H^{\prime}\right)$, Evenness index (e') to express similarity and dominance index $(\mathrm{C})$ to assess level dominance by certain taxa. Diversity of macrozoobenthic assemblages was expressed by the diversity index of Shannon-Wiener $\left(\mathrm{H}^{\prime}\right)$, using the following formula (Krebs, 1989):

$$
\mathrm{H}^{\prime}=\sum_{\mathrm{n}=\mathrm{i}}^{\mathrm{s}} \quad \mathrm{Pi} \ln \mathrm{Pi}
$$

Where, $\mathrm{H}^{\prime}=$ the Shannon diversity index; $\mathrm{Pi}=$ fraction of the entire; population made up of species $\mathrm{i} ; \mathrm{S}=$ numbers of species encountered; $\Sigma=$ sum from species 1 to species $S$.

Pielou's Evenness index expresses composition of a number of individuals in any genus that is within the community. It is gained by comparing index diversity with their maximum value and calculated by formula (Brower, 1990):

$$
\mathrm{e}^{\prime}=\frac{\mathrm{H}^{\prime}}{\mathrm{H}^{\prime} \max }
$$

Where, e': population index; H': the diversity index of Shannon Weiner species; H' max: maximum the diversity index/ln S.

The community dominance index is used dominance index (Odum, 1994) with the formula:

$$
\mathrm{C}=\Sigma \mathrm{pi}^{2}
$$

Where, $\mathrm{C}=$ dominance index; ni: number of individuals per species; $\mathrm{N}$ : the total number of individuals per species.

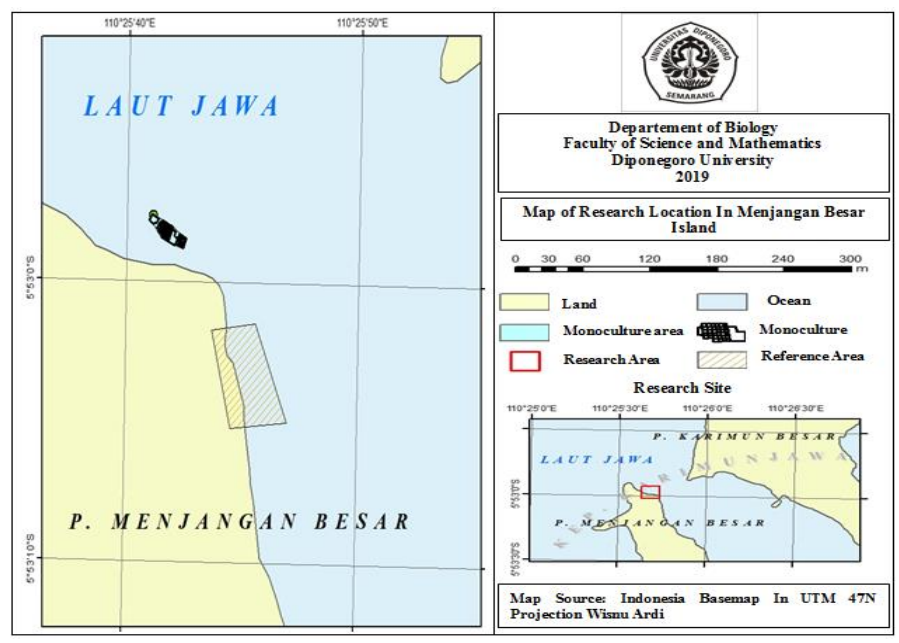

Fig. 1 Map of sampling sites at Menjangan Besar Island, Karimunjawa, Central Java, Indonesia as a study site.

\section{RESULTS AND DISCUSSION}

\section{The Amount of Macrozoobenthos Abundance}

This study found 89 species with the total abundance of 50,071 individuals $/ \mathrm{m}^{2}$, consisting of 52 families and 4 classes of macrozoobenthic i.e Gastropoda class were 52 species from 31 families, Bivalvia class were 26 species from 12 families, Polychaeta class were 8 species from 7 families, and Crustacea class were 2 species from 2 families (Table 1).

Table 1 Abundance of macrozoobenthic

\begin{tabular}{clcc}
\hline No & $\begin{array}{c}\text { Class of } \\
\text { macrozoobenthos }\end{array}$ & Familie & Species \\
\hline 1 & Crustacea & 2 & 2 \\
2 & Bivalvia & 12 & 26 \\
3 & Gastropoda & 31 & 52 \\
4 & Polychaeta & 7 & 8 \\
\hline
\end{tabular}

The results of identification, is a family of gastropoda and bivalva class with a fairly high distribution found in all in the two sampling locations. This is because Gastropoda and Bivalvia class can live and thrive on a wide variety of sedimentary structures and can adapt to waters dominated by silt and sand substrate types (Aufa et al., 2018).

\section{Diversity Index, Evenness Index, and Dominance Index}

The values of diversity index ( $\left.\mathrm{H}^{\prime}\right)$ in the first sampling time was highest in the monoculture with a value of 2,54 while the lowest was in the reference area with a value of 2,76 . The value of diversity index $\left(\mathrm{H}^{\prime}\right)$ in the second sampling time was highest in the reference area with a value of 3,40 , while the lowest index value is at the monoculture with the value of 3,34 (Fig. 2). Sampling is based on different time and has a long enough pause that the first sampling and the second sampling shows the index value of diversity index $\left(\mathrm{H}^{\prime}\right)$ of macrozoobenthic animals are considered high.

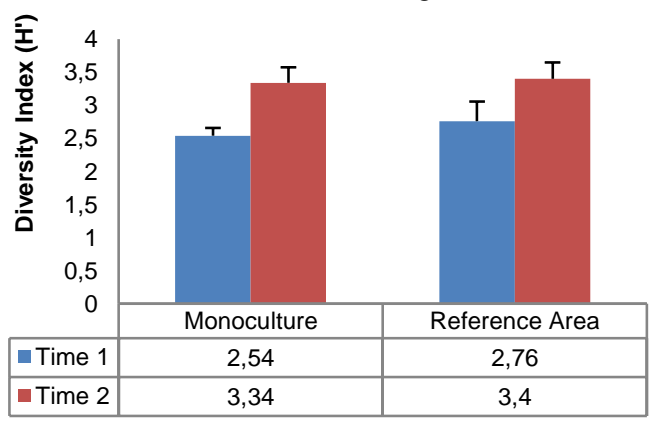

Fig. 2 Diversity index among sampling time sites 
The high biodiversity values are thought to be related to the ability of a amount of genus to tolerate environmental parameters where as the low value of the diversity index is thought to be due to an inability to compete for feeding with more adaptive biota (Odum, 1994), whilst the fluctuation of macrobenthic structure is a results of environmental changes respond spatially and temporally, especially food availability as the form of organic matter (Putro et al, 2018). The diversity of the genus in a community is judged to be low if its distribution is uneven, where certain species are found in abundant quantities but there are certain genus found only slightly (Aufa et al., 2018).

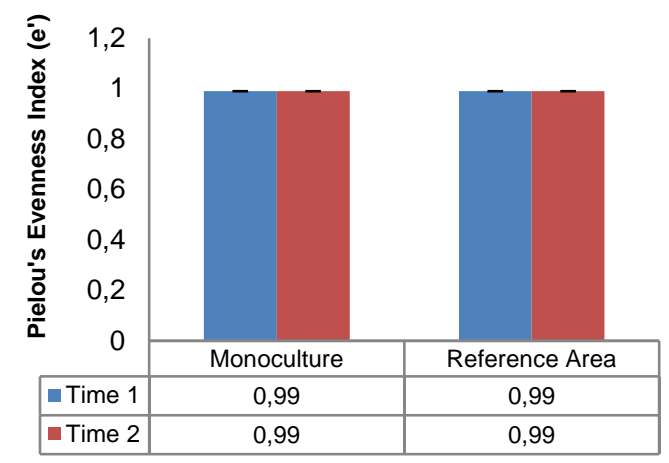

Fig. 3 Evenness index among sampling time sites.

Fig. 3, shows values of Pielou's evenness index, comparing the first sampling time and the second sampling time ranged between 0,99 . This indicates that the macrozoobenthic assemblages relatively evenly distributed among the sites and no indication of dominant taxa inhabiting the studied sites. The lowest value of the index occurred at the reference site, compared to monoculture sites. This may be because of the ecological pressure from activities in the surrounding waters, not only form spread out of organic material generated from fish farming but also can be from urban waste and industrial waste that is carried away by the waves (Putro et al., 2018).

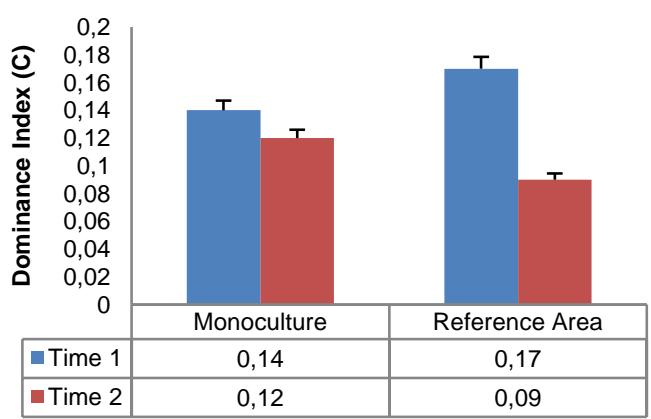

Fig. 4 Dominance index among sampling time sites.

The values of dominance index (C) ranged between 0,09-0,017 at all sampling sites (Fig. 4). The two sampling locations have a dominance of close to 0 so that it can be interpreted that there are no or few species that dominate the location of the research. According to Putro et al., (2014), the tendency of dominance values to approach 0 means that there is no type that dominates in the waters, which means that in each individual at the observation location has the same and maximum opportunity to utilize resources in the waters.

\section{Physical-Chemical Water Factors at Menjangan Besar Island}

Physical-chemical water factors measured at the monoculture and reference area were dissolved oxygen, salinity, temperature, $\mathrm{pH}$, water current, nitrogen, and carbon. The physical and chemical data obtained were $\mathrm{pH}(8,08-8,1), \mathrm{DO}(5,03-8,05 \mathrm{mg} / \mathrm{l})$, salinity $(26,3-$ $33,6 \%$ o $)$, temperature $\left(28,6-33^{\circ} \mathrm{C}\right)$, and water current $\left(3,5-10 \mathrm{~cm} \cdot \mathrm{s}^{-1}\right)$. It can be concluded that factors values of physical-chemical water were recorded within normal range over the study period, as shown in Fig. 5.

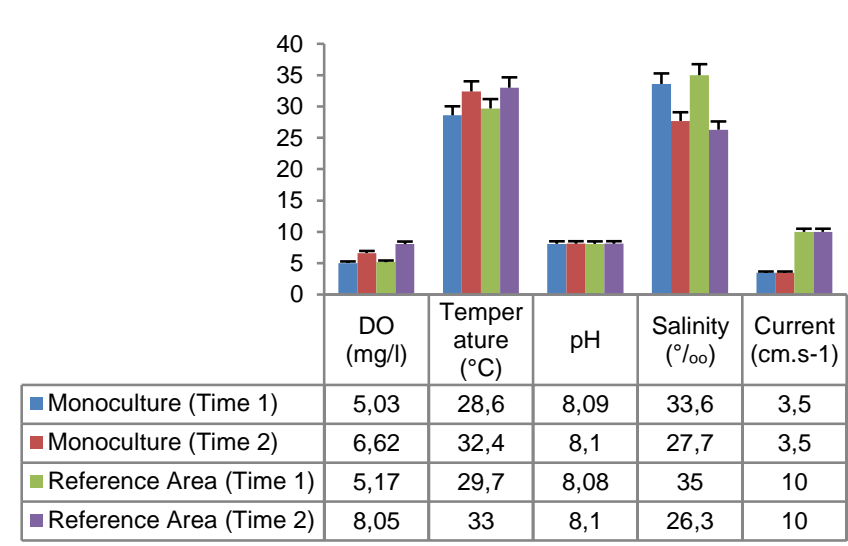

Fig. 5 Physical-chemical water factors at the Menjangan Besar Island

The results of DO measurements at the observation site varied considerably in the range of 5,03-8,05 $\mathrm{mg} / \mathrm{l}$. in the data collection location, DO values obtained indicate that the waters are in very good condition, and still meet seawater quality standards in The Menteri Lingkungan Hidup No. 512004 years for marine biota life with DO values $>5 \mathrm{mg} / \mathrm{l}$, so DO concentrations in the waters of Menjangan Besar Island are still classified as suitable for marine biota.

Temperatures obtained at the study were $28,6-33^{\circ} \mathrm{C}$. The temperature value at this study site is good for macrozoobenthic life and is in the normal range, this is in accordance with the Izzah et al., (2016), statement that is the ideal temperature for growth of macrozoobenthic were $25-35^{\circ} \mathrm{C}$. The measurement of water current at the location of this study ranged from $3.5 \mathrm{~cm} \cdot \mathrm{s}^{-1}$ to $10 \mathrm{~cm} \cdot \mathrm{s}^{-1}$. The water current between $3-39 \mathrm{~cm} / \mathrm{s}$ belongs to the medium current category and is still below the threshold for macrozoobenthic animal life (Zulfiandi, 2003). The water current is a factor that limits the spread of macrozoobenthic, where will affect the types of macrozoobenthic. The water current will affect the distribution of sediments which will later form a basic substrate that will become a habitat for macrozoobenthic animals in the waters (Irmawan et al., 2010).

Salinity at all sampling locations was still within limits of tolerance for farmed and macrozoobenthic organism life. According to Sharani et al., (2018), optimum salinity for gastropoda (26-32\% and bivalva $(24-36 \%$ ). Based on the Menteri Lingkungan Hidup (2004), standard of salinity for marine biota were 33-34 ppt. pH on the coast of Menjangan Besar island in the two sampling locations is still normal between 8,09 to 8,1 and allows for benthos animals to live. The $\mathrm{pH}$ range that can still be tolerated benthos animals is 6,58,5 (Aininnur et al., 2015).

\section{Sediment Properties: Organic Content and Sediment Grain Size}

Based on the analysis, the average carbon content ranged from $0,493-2,07 \%$ and the nitrogen content ranged from 0,025-1,74\% (Fig. 6).

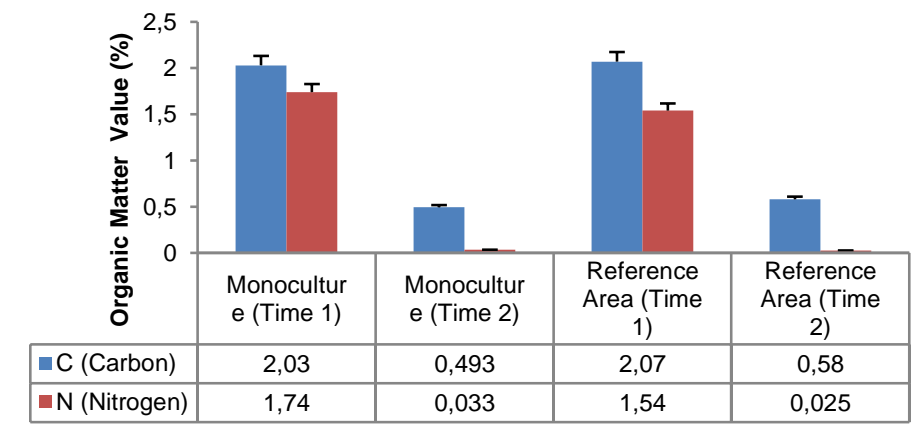

Fig. 6 Proportion of organic content of Carbon and Nitrogen at the Menjangan Besar Island. 
Substrate organic content is a food source for a variety of organisms and for macrozoobenthic animals in particular (Putro, 2007). The source of nitrogen and carbon organic in the waters comes from the decay of living things that have died while the anthropogenic source is derived from fishery activities (Effendi, 2003). The nitrogen content in the first sampling time averaged 1,74-1,54, while the second sampling time averaged $0,025-0,033$. The carbon content in the first sampling time averaged 2,03-2,07 and the second sampling time averaged 0,493-0,580.

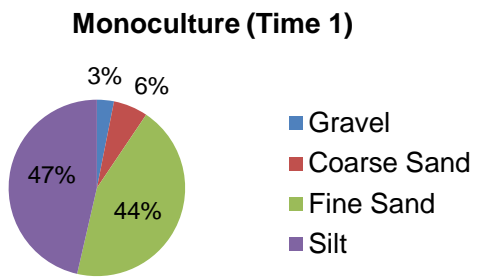

\section{Reference Area (Time 1)}

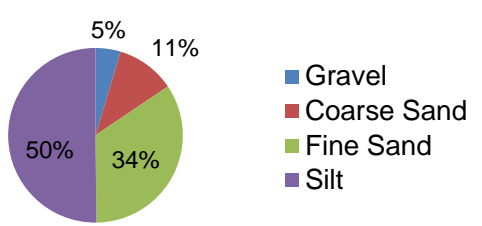

Carbon and nitrogen levels during the first and second sampling time sessions at all two locations were considerably different. This is thought to be the effect of the intervals between the first and second sampling time sessions during which organic matter was influenced by aquacultural activities as well as by strong currents that can deliver organic matter causing accumulation in the area (Syuja' et al., 2018).

Figure 7. Composition of sediment grain size at the Menjangan Besar Island.

According to Borja et al., (2000), stated that silt sediment can be affected by high suspended particles in waters, resulting in low oxygen levels in the sediment. Type of substrate in water is considerably important for the growth of the macrozoobenthic community. The sand substrate may make it easier to macrozoobenthic move to another place than silty substrate that contains less oxygen. Therefore the organisms live in silty substrate have to adapt under these circumstances. Macrozoobenthic of Bivalvia, Gastropoda, and Polychaeta were found in silty sampling sites. The Bivalvia and Gastropoda species have a wider spread because they are able to adapt to marine habitats with soft or hard sedimen textures (Sharani et al., 2018).

\section{Linking chemical and physical parameters to macrobenthic assemblages}

The table 2, shows the correlations between physical-chemical factors, substrate granular composition and the carbon and nitrogen content with the abundance of macrozoobenthic were analyzed using BI-OENV on PRIMER V.6.1.5 software. Nitrogen and silt were the most chemical and physical factors influencing the structure of macrozoobenthic $(r=0,632$; BIO-ENV).

Table 2. Analysis of the correlation between biotic and abiotic component

\begin{tabular}{cccc}
\hline No & $\begin{array}{c}\text { Correlation } \\
\text { Coefficient (r) }\end{array}$ & Variable* $^{*}$ & $\begin{array}{c}\text { Variable } \\
\text { Amount }\end{array}$ \\
\hline 1 & 0,632 & 7,11 & 2 \\
2 & 0,617 & $1,6,7,9,10$ & 5 \\
3 & 0,617 & $1,3,6,7,9$ & 5 \\
4 & 0,616 & $1,3,6,7,10$ & 5 \\
5 & 0,615 & 6,7, & 2 \\
6 & 0,615 & $6,7,11$ & 3 \\
7 & 0,614 & $1,6,9,10$ & 4 \\
8 & 0,614 & $1,6,9,10,11$ & 5 \\
\hline
\end{tabular}

*Variables: (1) pH; (2) Temperature; (3) Salinity; (4) DO; (5) Water urrent; (6) Carbon; (7) Nitrogen; (8) Gravel; (9) Coarse Sand; (10) Fine Sand; (11) Silt.
This may imply that nitrogen in sediment of marine waters is a basic requirement that affects in growth and reproductive control of macrobenthic organisms. Therefore, the sedimentary substrate greatly determines abundance and distribution of macrobenthic = community. The high organic matter (Nitrogen) at farmed sites, especially in first sampling time may be generated from accumulation of organic matter (nutrient enrichment) from the residual feed and residual feces during farming activities in sediments and water column. Stated that sediments that have high organic matter can support an abundance of infauna dominated by deposit feeders (Putro et al., 2018). Furthermore, Stated that source of organic nitrogen in water column is mainly produced from decay process of living things that have died, while anthropogenic source is derived from fishery and industrial activities (Sharani et al., 2018).

\section{CONCLUSION}

Macrobenthic assemblages consisted of 89 species with the total abundance of 50,071 individuals $/ \mathrm{m}^{2}$, consisting of 52 families and 4 classes of macrozoobenthos. Diversity and evennes indices exhibited differed by location (monoculture vs reference) and time sampling. Fluctuation of macrobenthic structure was considered as a results of environmental changes spatially and temporally, especially sediment composition and food availability as the form of organic matter. The values of indices were ranging from 2,54-3,40 for diversity index $\left(\mathrm{H}^{\prime}\right)$, 0,99 for Pielou's evenness index (e'), and 0,09-0,17 for dominance index (C). The most common classes were a member of Gastropoda and Bivalvia. Nitrogen and silt were the most chemical and physical factors influencing the structure of macrozoobenthos $(r=0,632$; BIOENV).

\section{ACKNOWLEDGEMENT}

The authors would like to thank Directorate General of Higher Education (Simlitabmas-DIKTI) for financially supporting this research project under the scheme of 'Excellent Research For 
National Strategic Grant (PUSN) year 2018-2020' project. The study. was supported by Marine and Fishery Service (DKP), Central Java Province, Central for Brackish Water Aquaculture Development (BBPBAP) Jepara, Center of Marine Ecology and Biomonitoring for Sustainable Aquaculture (Ce-MEBSA), Marine Science Techno Park (MSTP) Undip and Laboratory of Ecology and Biosystematics, Biology Department, Faculty of Science and Mathematics, Diponegoro University.

\section{REFERENCES}

Aininnur, A., Putro S.P., Fuad, M. 2015. Hubungan faktor fisika-kimia perairan terhadap kelimpahan moluska di area keramba jaring apung sistem polikultur Teluk Awerange, Sulawesi Selatan [The relationship of physical-chemical factors of waters to the abundance of molluscs in the floating cages of policulture system in the Teluk Awerange, South Sulawesi]. Jurnal Biologi, 4(4). 47-52.

Aufa, A., Hadi M., Putro, S.P. 2018. Spatial and temporal patterns of macrozoobenthic community inhabiting sediments under tropical fish farming. Journal of Physics: Conference Series. 1025, 1-7.

Borja, A., Franco, J., Pe'rez, V. 2000. A marine biotic index to establish the ecological quality of soft-bottom benthos within european estuarine and coastal environments. Marine Pollution Bulletin. 40, 1100-1114.

Brower, J.E., Zar, J.H., Ende C.N.V. 1990. Field and laboratory methods for general ecology dubuque. WCB Publishers. pp. 226

Clarke, K.R., Gorley, R.N. 2006. Primer v6: user manual/ tutorial. PRIMER-E, Playmouth. pp. 176.

Dauvin, J.C., Thiebaut, E., Gesteira J.L.G., Ghertsos, K., Gentil, F., Ropert, M., Sylvand, B. 2004. Spatial structure of a subtidal macrobenthic community in the Bay of Veys (Western Bay of Seine, English Channel). J. Exp. Mar. Bio. Ecol, 307, 217-235.

Direktorat Pendayagunaan Pesisir dan Pulau-Pulau Kecil (DPPK) [Directorate of Coastal and Small Islands Utilization]. 2012. Menjangan Besar. Available at: http://www.ppkkp3k.kkp.go.id/direktoripulau/index.php/public_c/pulau_info/ 4303. (Accessed: 4 May 2018).

Effendi, H. 2003. Telaah kualitas air: bagi pengelolaan sumberdaya dan lingkungan perairan [Review water quality: for resource management and the aquatic environment]. Kanisius. Yogyakarta, Indonesia. pp. 50-66.

Hernandez-Arana, H.A., Rowden, A.A., Attrill, M.J., Warwick, R.M., Bouchot, G.G. 2003. Large-Sc ale environmental influences on the benthic macroinfauna of the Southern Gulf of Mexico. Estuar. Coast. Shelf Sci. $58,825-841$.

Husain, T.K., J.H. Mulyo., Jamhari. 2016. Comparative analysis of benefits and risks of fisheries business with monoculture and policultural systems in Pangkep Regency. Agro Ekonomi. 27(2), 136-149.

Indarjo, A. 2014. Pemetaan kawasan ekowisata selam di perairan Pulau Panjang, Jepara, Jawa Tengah. Jurnal Harpodon Borneo. 7(2), 88-92.
Izzah, A., Roziaty, E. 2016. Keanekaragaman makrozoobentos di pesisir pantai Desa Panggung Kecamatan Kedung Kabupaten Jepara [The diversity of macrozoobenthos on the coast of Panggung Village, Kedung District, Jepara Regency]. Bioeksperimen. 2(2), 140-148.

Irmawan, R.N., Zulkifli, H., Hendri, M. 2010. Struktur komunitas makrozoobentos di Estuaria Kuala Sugihan Provinsi Sumatera Selatan [Structure of the macrozoobenthos community in the Estuaria Kuala Sugihan, South Sumatra Province]. Maspari Journal. 01, 53-58.

Krebs, C.J. 1989. Ecological methodology. New York: Harper Collins Publishers. pp. 654.

Menteri Lingkungan Hidup [Ministry of Environment]. 2004. Peraturan No. 51: Standar Air Laut [Decree No. 51: Standard of Sea Water]. MLHK. Jakarta, Indonesia. pp. 1493-1497.

Odum, E. P. 1994. Dasar-dasar ekologi [The Basics of Ecology]. Translation in indonesia (by Tjahjono Samingan). Edition 3. Gadjah Mada University Pess. Yogyakarta. pp. 200-697.

Pamuji, A., Muskananfola, M.R., A'in, C. 2015. The effects of sedimentation on macrozoobenthos abundance in Betahlawang estuary of Demak. Jurnal Saintek Perikanan. 10(2), 129-145.

Prahmawaty, R.F., Putro, S.P., Hariyati, R. 2018. Struktur komunitas makrobentos pada kawasan budidaya dan non budidaya di Pulau Tembelas, Kabupaten Karimun Kepuluan Riau [The structure of the macrozoobenthos community in the cultivation and non-cultivation areas on Tembelas Island, Karimun Regency, Riau Islands]. Bioma. 20(10), 6674.

Putro, S.P. 2007. Spatial and temporal patterns of the macrobenthic assemblages in relation to environmental variables. Journal of Coastal Development. 10(3), 15-22.

Putro, S.P., Widowati, Suhartana, Fuad, M. 2015. The application of integrated multi trophic aquaculture sustainability. Int. J. Sci. Eng. 9, 86-89.

Putro, S.P., Febria, I.J., M. Fuad. 2014. Comparative study of characteristicsol sediment and water quality aquaculture farming systems area with coastal area adjacent to industrial activities. Jurnal Sains dan Matematika (JSM). 22(3), 79-83.

Putro, S.P., Widowati, Cheshire, A. 2018. Linking chemical and physical parameters of a coastal water ecosystem with macrobenthic assemblages to assess environmental disturbance. Malaysian Journal of Fundamental and Applied Sciences. 14(1): 78-82.

Sharani, J., Hidayat, J.W., Putro, S.P. 2018. Correlation between macrobenthic structure (biotic) and water-sediment characteristics (abiotic) adjacent aquaculture areas at Tembelas Island, Indonesia. Journal of Physics: Conference Series. 1025, 1-8.

Syuja', M.A., Putro, S.P., Fuad, M. 2018. Biomonitoring on integrated multithopic aquaculture (IMTA) activities using macrobenthic mollusks on Tembelas Island, Kepulauan Riau Province. Journal of Physics: Conference Series. 1025, 1-6.

Zulfiandi. 2012. Struktur komunitas makrozoobenthos di perairan Pandansari Kecamatan Sayung, Kabupaten Demak [Structure of the macrozoobenthos community in Pandansari waters, Sayung Subdistrict, Demak Regency]. Journal of Marine Research. 1(1), 62-66. 